\title{
Using Voronoi diagrams to describe tactical behaviour in invasive team sports: an application in basketball
}

\author{
Aplicácion de diagramas de Voronoi para describir el comportamiento \\ táctico en deportes de equipo de invasión: una aplicación en el baloncesto
}

\section{Usando diagramas de Voronoi para descrever o comportamento tático em esportes de equipe invasivos: uma aplicação no basquete}

\author{
António Lopes ${ }^{1 *}$, Sofia Fonseca ${ }^{1}$, Roland Lese ${ }^{2}$ y Arnold Baca ${ }^{2}$ \\ ${ }^{1}$ Faculty of Physical Education and Sports, Lusófona University, Lisbon, Portugal, \\ ${ }^{2}$ Department of Biomechanics, Kinesiology and Applied Computer Science, Centre for Sport Science and University Sports, University of Vienna, Austria
}

\begin{abstract}
Team sports are recognized as dynamic systems of interaction, where individual and collective patterns of behaviour emerge from a confluence of multiple constraints on the players. Players' distribution on the field is often associated with tactical options, strategic decisions, and principles. Hence, the analysis of positional data has gained relevance and is now a hot topic in sport science research, feeding the interests of researchers, analysts and coaches.

Recent studies tried to characterize teams' and players' tactical behaviour using variables derived from their spatial distribution (e.g., the area of the convex hull). The Voronoi diagrams (VD) have been introduced for the analysis of the spatial organization in team sports as it allows, unlike other models, defining the dominant region of both players and teams.

This study considered the application of VD to describe offensive tactical behaviour in basketball. For this purpose, a formal game between two teams of Austrian basketball talents was observed, from where 19 offensive sequences were selected for analysis. The results indicate that the percentage of area occupied by each team, at each instant, can be considered to describe teams' patterns of spatial organization during a positional attack, allowing to classify and distinguish transition phase and organized phase. This approach may also help to reduce the time spent in video analysis by coaches, giving them more time to prepare training plans and sessions in order to improve the tactical and strategic performance of their teams.
\end{abstract}

Keywords: Voronoi diagrams, basketball, tactical behavior, spatial organization.

Resumen: Los deportes de equipo son reconocidos como sistemas dinámicos de interacción, donde patrones individuales y colectivos de comportamiento surgen de la confluencia de múltiples condicionantes sobre los jugadores. La distribución de los jugadores en el campo se asocia con opciones tácticas, decisiones estratégicas y principios de juego. Por lo tanto, el análisis de los datos de posición se ha ganado relevancia y ahora es un tema importante en la investigación, correspondiendo a las necesidades de los investigadores, analistas y entrenadores.

Estudios recientes trataron de caracterizar el comportamiento táctico de equipos y jugadores usando variables derivadas de su distribución espacial (e.g., el área de la envolvente convexa). Los diagramas de Voronoi (DV) se han introducido para el análisis de la organización espacial en deportes

Dirección para correspondencia [Correspondence address]: António Lopes. Faculty of Physical Education and Sports. Lusófona University. Campo Grande 376. 1749-024 Lisboa (Portugal). de equipo ya que permite definir, a diferencia de otros modelos, la región dominante dos jugadores y dos equipos.

Este estudio examinó la aplicación de DV para describir lo comportamiento táctico ofensivo en baloncesto. Con este fin, un juego informal entre dos equipos de talentos Austriacos fue considerado de donde 19 secuencias ofensivas fueron seleccionados para análisis. Los resultados indican que el porcentaje de superficie ocupada por cada equipo, se puede considerar para describir patrones de comportamiento de los equipos durante un ataque posicional, en particular, clasificar y distinguir la fase de transición y la fase organizada. La aplicación práctica de estos resultados puede ayudar a reducir el tiempo empleado en el análisis de vídeo por los entrenadores, dándoles más tiempo para preparar los planes de formación y sesiones con el fin de mejorar el rendimiento táctico y estratégico de sus equipos.

Palabras clave: Diagramas de Voronoi, baloncesto, comportamiento táctico, organización espacial.

Resumo: Os deportos coletivos são reconhecidos como sistemas de interação dinâmica, onde padrôes de comportamento individual e coletivo emergem da confluência de vários constrangimentos sobre os jogadores. A distribuição dos jogadores no campo está associado a opçóes táticas, decisóes estratégicas e princípios de jogo. Assim, a análise de dados posicionais ganhou relevância no âmbito da investigaçáo sendo agora um tópico importante, já que responde às necessidades dos investigadores, analistas e treinadores.

Estudos recentes têm procurado caracterizar o comportamento tático das equipas e jogadores através de variáveis derivadas da sua distribuição espacial (e.g., área do fecho convexo). Os diagramas de Voronoi (DV) foram introduzidos para a análise da organização espacial das equipas em desportos colectivos de invasão uma vez que permite, ao contrário de outros modelos, definir a regiáo dominante dos jogadores e das equipas.

Este estudo considerou a aplicação dos DV para descrever o comportamento tático ofensivo no basquetebol. Para este efeito, foi observado um jogo informal entre duas equipas de talentos Austriacos, do qual foram selecionadas 19 sequências ofensivas para análise. Os resultados indicam que a percentagem de área ocupada por cada equipa permite descrever padróes de comportamento das equipas durante um ataque posicional, particularmente, classificar e distinguir a fase de transiçấo e a fase organizada. A aplicação prática destes resultados podem ajudar a reduzir o tempo gasto pelos treinadores na análise de vídeo dando-lhes mais tempo para preparar sessóes de treino e acçóes de formação a fim de melhorar o desempenho tático e estratégico das suas equipas. Palavras chave: Diagramas de Voronoi, basquetebol, comportamento táctico, organização espacial. 


\section{Introduction}

Team sports are a major study object in sport science research. The interest on studying players and teams has increased over the years and, although physiological and biomechanical approaches have been privileged (Garganta, 2009), the interest in studying tactical behaviour of teams and players has seen a huge increase in the last few years. This phenomena is a consequence of a strong orientation towards a healthy and fruitful bond between research, training and competition in team sports (Garganta, 2009).

The analysis of tactical behavior in team sports of an invasive nature (e.g., soccer, basketball and handball) has aimed to define measures that can effectively capture and describe behavioural patterns of interest. At each instant of the game, the spatial organization of teams and players mirror the collective and individual tactical options, which are related with fundamental game principles. For instances, the creation and occupation of space is associated with the players' spatial organization in width and depth (movement of attacker players to extend and use the effective play-space).

The availability of players' positional data, allied to a dynamical system theory approach (Glazier, Davids, \& Bartlett, 2003; Glazier, 2010; Lebed, 2006; McGarry, Anderson, Wallace, Hughes, \& Franks, 2002; McGarry \& Franks, 2007; Reed \& Hughes, 2006), allows studying teams' tactical performance through spatial measures. Hence, current research has considered spatial team variables derived from players' positional data, such as the surface area: area of the smallest convex set that contains all players of a team (Bartlett, Button, Robins, \& Dutt-Mazumder, 2012; Bourbousson, Sève, \& McGarry, 2010; Clemente, Couceiro, \& Martins, 2012; Frencken \& Lemmink, 2008; Frencken, Lemmink, Delleman, \& Visscher, 2011; Martins, Clemente, \& Couceiro, 2013; Moura et al., 2013), the area of the bounding rectangle: area of the minimum unrotated rectangle that contains all players of a team (Lopes, Fonseca, Leser, \& Baca, 2013), the stretch index: mean distance of teammates from the spatial centre (Bartlett et al., 2012; Bourbousson et al., 2010; Folgado, Lemmink, Frencken, \& Sampaio, 2012; Okihara et al., 2004; Travassos, Araújo, Correia, \& Esteves, 2010) and the Voronoi area: area of the team as the sum of the area of the voronoi cells of all teammates (Fonseca, Milho, Travassos, \& Araújo, 2012; Fonseca, Milho, Travassos, Araújo, \& Lopes, 2013; Lopes et al., 2013; Gazimba, Duarte, \& Araújo, 2013; Fujimura \& Sugihara, 2005; Kim, 2004; Law, 2005).

Despite the variety of variables so far suggested to study tactical behavior in team sports, and their proven ability to describe teams' intra- and inter- spatial behavior during a game or task, it has already been stated (Lopes et al., 2013) that some variables present limitations due to their geometrical construction, neglecting some fundamental characteris- tics of the game: for example, the surface area generates two independent shapes, each associated to a team, that can overlap, and therefore their area is not an accurate estimator of teams' space dominance. Unlike this, the Voronoi diagrams (Voronoi, 1907), follow a method of construction that generates individual and exclusive cells in the field, each associated to a player, and for this reason, the application of this method has been privileged.

Recalling the game principles mentioned earlier, in a offensive sequence of a team sport of an invasive nature, attackers are expected to increase their play space, i.e., create width and depth and hence increase their covered area, while defenders, in response, concentrate and protect the goal area, covering less area in the field (Gréhaigne \& Godbout, 2014). These principles are expected to be well captured by the Voronoi diagram. Thus, this investigation aims to assess how game principles are put into practice in a basketball game and how they can be identified by means of the percentage of Voronoi area (VA), which measures the percentage of area in the field occupied by each team.

\section{Methods}

\section{Participants}

Twenty (20) male basketball players from the national talents of Austria participated in this study (age: $16.05 \pm 2.09$ years old, height: $183.10 \pm 5.88 \mathrm{~cm}$, weight: $73.13 \pm 8.10 \mathrm{~kg}$, trainings frequency per week: $7.25 \pm 1.29$ times, $10.88 \pm 1.94$ hours). A formal game, played in a $28 \mathrm{~m}$ width $\times 15 \mathrm{~m}$ depth field, was video recorded and players' trajectories were automatically extracted during the game by means of a radio wave based local positioning system (Leser, Schleindlhuber, Lyons \& Baca, 2014).

\section{Sample}

Following observational methodology procedures (Anguera \& Hernández-Mendo, 2013), nineteen (19) sequences of positional attack (PA) of one team were extracted from the whole game. According to the two Portuguese basketball experts invited to collaborate in this study (Table 1), a valid sequence is characterized by the following criteria: (1) the observed team starts the sequence with ball possession in its midfield, (2) the ball is carried towards the basket, (3) all ten players must have crossed the midfield line, (4) after this there must be at least two interactions between the ball carrier and his teammates (5) the sequence finishes with an attempt to throw to the basket. The average length of the sequences was $15.1 \pm 3.73$ seconds. 
Table 1. Characterization of the experts invited to participate in the present study.

\begin{tabular}{lccccc}
\hline Experts & Level & $\begin{array}{c}\text { Experience } \\
\text { (years) }\end{array}$ & Nationality & License type & $\begin{array}{c}\text { Age } \\
\text { (years) }\end{array}$ \\
\hline A & Youth & 50 & Portuguese & IV & 69 \\
B & Youth & 15 & Portuguese & III & 39 \\
\hline
\end{tabular}

\section{Procedures}

The percentage of VA of both teams was calculated at each frame of a sequence according to the following algorithm:

1. The coordinates of all players within an area of $28 \times 15 \mathrm{~m}^{2}$ (court) are considered.

2. A grid of $0.1 \times 0.1 \mathrm{~m}^{2}$ squares is superimposed over the court.

3. Each square in the grid is associated to the nearest player considering the distance of each player to its midpoint.

4. The VA of a player is given by the sum of the squares closer to him than to all other players.

5. The VA of a team is given by the sum of the VAs of all players of this team.

6. The percentage of VA of a team is calculated by the VA of that team divided by the total area.

7. The VA of the other team is the remaining percentage.

In order to distinguish patterns of different spatial organization, we followed the procedures described in Fonseca et al. (2013) to calculate reference values of the percentage of VA. Accordingly, the $95 \%$ confidence envelopes were determined based in 1.000 simulated patterns of complete spatial randomness (CSR), as an indicator of a transition phase (i.e., transition between defensive and offensive phases), also designated reorganization (Bayer, 1986; Gréhaigne, Godbout, \& Bouthier, 1999; Mitchell, Oslin, \& Griffin, 2006). The simulations were performed respecting the present setup (game field dimensions of $28 \times 15 \mathrm{~m}^{2}$ and five players per team) and the obtained $95 \%$ confidence limits were $31 \%$ and $69 \%$. Thus, for a given time on a sequence, a percentage of VA within these values would be associated with a transition phase from an offensive phase (for which values would be above $69 \%$ ) to a defensive phase (for which values would be below 31\%).

\section{Results}

Next are presented the results from the analysis of the spatial organization of the teams in each sequence of positional attack (PA). The percentage of VA occupied by each team was calculated across the duration of each sequence and is plotted in the Figure 1 for all sampled sequences along with the 95\% confidence envelopes for transition phase.

According to the invited experts, all basketball sequences of positional attack are divided in two moments: (1) a transition phase, which develops quickly as soon as ball possession is gained, until the midfield line is crossed by all players, followed by (2) an organized phase, played in a different pace, where players occupy specific positions in the field to prepare and start a set play. Theoretically, and based on the game principles, the spatial organization of the teams in these two phases is distinct, and it is possible to relate these with the observed values of the percentage of VA. Specifically, in the beginning of an offensive sequence, and before the midfield line is crossed by all players (transition phase), the percentage of VA of the attacking team is expected to be within the limits of the $95 \%$ confidence envelopes for CSR. After that (organized phase), the percentage of VA of the attacking team is expected to be greater than $69 \%$, corresponding to a structured attacking phase.

In Figure 1, below, are shown the observed values of the percentage of VA of each team across the duration of each sequence (transition phase $\mid$ organized phase) in our sample $(n=19)$. These values are compared with the reference values from the $95 \%$ confidence envelopes for CSR. 
Figure 1. Percentage of VA of the attacking team (black line) and the defending team (grey line) and 95\% confidence envelopes (dashed lines) of each sequence of positional attack $(\mathrm{n}=19)$. The vertical black line marks the moment when all players crossed the midfield line.

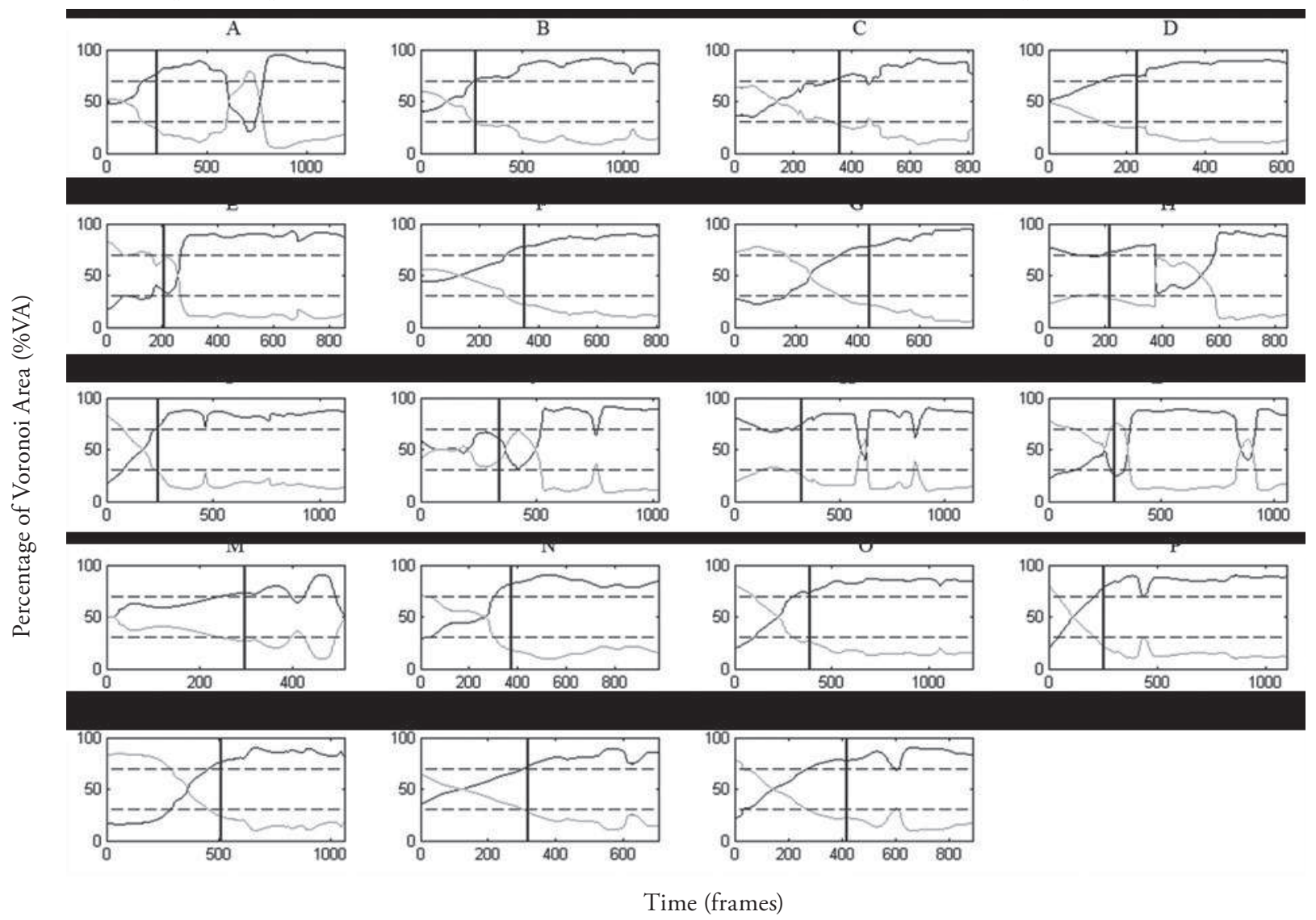

Transition phase

Based on the plotted data (Figure 1), and before the midfield line has been crossed by all players (transition phase), three different patterns of spatial organization can be identified: (1) typically, this phase starts in the beginning of the sequence with values of the percentage of VA between 31\% and 69\% and this pattern is well observed in sequences $\mathrm{A}, \mathrm{B}, \mathrm{C}, \mathrm{D}, \mathrm{F}$, J, M, N and R (Figure 1); (2) another pattern of transition is observed when a sequence starts with values of the percentage of VA of the attack below 31\% (sequences E, G, I, L, O, P, $\mathrm{Q}$ and S); (3) the third pattern is observed when a sequence starts with values of the percentage of VA of the attacking team above $69 \%$ (sequences $\mathrm{H}$ and $\mathrm{K}$ ).

\section{Organized phase}

The organized phase follows the transition phase. Based on the plotted data (Figure 1), during this phase the observed values of the percentage of VA of the attacking team are typically above $69 \%$. This pattern was observed in all sampled sequences, although in some sequences these values were not constantly over $69 \%$ (sequences A, H, J, K and L), being temporarily within $31 \%$ and $69 \%$.

\section{Discussion}

The current state of the art in analyzing the teams' and players' behaviour by means of different kinds of metrics (e.g. Bartlett et al., 2012; Davids \& Araújo, 2010; Folgado et al., 2012; Frencken et al., 2011; Passos et al., 2011; Sampaio \& Maçãs, 2012), is lacking a meaningful assessment of players' and teams' owned space (McGarry, 2009). The variables considered to characterize game behaviour are usually not taking into account the fundamental attributes of the match as well as its tactical principles (Lopes et al., 2013). In team sports, players of a team are distributed in the field according to a number of factors that determine their spatial organization. In the offense, for instance, players usually keep more distance between each other in order to cover more space, which yields to more opportunities for efficient actions. On the other hand, the defending team is more concentrated within a more confined area as defending players try to shorten the opportunities of the other team to score (i.e.: Bayer, 1984; 
Gréhaigne, Godbout \& Bouthier, 1999; Mitchell, Oslin \& Griffin, 2006).

Based on this, the main purpose of the present study was to extend current knowledge on the use of spatial metrics, specifically those derived from the Voronoi diagrams, to characterize collective behaviour in team sports, particularly in basketball. According to our results, and considering the 95\% confidence envelopes of the percentage of VA for CSR simulated patterns, [31, 69]\%, it appears that the observed percentage of VA of the attack team allows to discriminate between transition phase (observed values of the percentage of VA within the confidence limits) and organized phase (observed values of the percentage of VA above the upper limit) during an offensive process, particularly in a positional attack. Further, we have identified specific patterns of spatial organization in each of these two phases, as presented in Table 2 .

Table 2. Summary of the patterns identified for the transition and organized phase of the positional attack, and correspondence with the observed values of percentage of Voronoi area of the attacking team.

\begin{tabular}{ccc}
\hline $\begin{array}{l}\text { Observed \% of } \\
\text { Voronoi area of the } \\
\text { attacking team }\end{array}$ & Transition phase & Organized phase \\
\cline { 2 - 3 } & Delayed transition & NA* $^{*}$ \\
{$[31,69] \%$} & Effective transition & $\begin{array}{c}\text { Attempt to score } \\
\text { Penetration in the } \\
\text { defensive structure } \\
\text { Interception attempt }\end{array}$ \\
$>69 \%$ & Rash transition & \begin{tabular}{c} 
Structured attack \\
\hline Not Applicable
\end{tabular} \\
\hline
\end{tabular}

A Delayed transition occurs when the percentage of VA of the attack team is below the lower limit of the confidence envelope, $31 \%$, in the beginning of the transition phase, indicating that the attacking team is still very concentrated and is in spatial disadvantage. As the attacking team gains ball possession, they try to free up space to progress in the field, while protecting the ball from the opponents. A Rash transition occurs when, soon after ball possession was gained (transition phase), the percentage of VA of the attack team is above the upper limit of the confidence envelope, 69\%, in the beginning of the transition phase, indicating that the team has assumed spatial advantage in the field as soon as it gained ball possession. During the organized phase, the percentage of VA is typically above 69\% (Structured attack) as the attacking team has optimized their play in width and depth. However, during this phase, observed values within the confidence limits $([31,69] \%)$ can occur and seem to be associated to specific actions, such as attempts to score, penetrations in the defensive structure and interception attempts. Lastly, Effective transition and Structured attack are the expected patterns in the transition phase and organized phase, respectively.

In general, the identified patterns are in accordance with tactical principles of the attack in basketball (Oliveira \& Graça, 1998). The attacking team tends to play in depth and width to attract the defensive players away from central positions and/or locations near the basket, increasing progressively the percentage of VA in order to guarantee spatial advantage in the organized phase (Gréhaigne \& Godbout, 2014). Although these findings look prominent, the limitations pointed out in previous studies should be taken into consideration (Fujimura \& Sugihara, 2005; Taki, Hasegawa, \& Fukumura, 1996; Fonseca et al., 2012 and Lopes et al., 2013) in future work. However, the percentage of VA has proven to be a spatial variable able to describe game contexts, players' behaviour and eventually teams' strategies.

\section{Practical applications}

In this paper we introduced the use of Voronoi diagrams in a basketball game for identifying specific moments in a game, particularly during positional attack sequences. The percentage of VA of a team appears to capture relevant information regarding a teams' spatial organization, which is well associated with tactical rules being aware for this specific set-up. In an applied perspective, this approach may contribute not only for a better understanding of teams' tactical behavior but also to save time in video analysis, as it allow to identify the period of time in the game where specific game phases occur and therefore get directly to the video clips which are worth to consider in a video session, giving coaches more time to prepare training plans and sessions in order to improve the tactical and strategic performance of their teams.

Acknowledgments: The first author gratefully acknowledges the support of the Spanish government project Observación de la interacción en deporte y actividad física: Avances técnicos y metodológicos en registros automatizados cualitativos-cuantitativos (Secretaría de Estado de Investigación, Desarrollo e Innovación del Ministerio de Economía y Competitividad) during the period 2012-2015 [Grant DEP201232124]. 


\section{References}

1. Anguera, M. T., \& Hernández-Mendo, A. (2013). La metodología observacional en el ámbito del deporte. E-balonmano.com: Revista de Ciencias del Deporte, 9(3), 135-160.

2. Bartlett, R., Button, C., Robins, M., \& Dutt-Mazumder, A. (2012). Analysing Team Coordination Patterns from Player Movement Trajectories in Soccer: Methodological Considerations. International Journal of Performance Analysis in Sport, 12(2), 398-424.

3. Bayer, C. (1986). La enseñanza de los juegos deportivos colectivos. Barcelona, Spain: Editorial Hispano Europea.

4. Bourbousson, J., Sève, C., \& McGarry, T. (2010). Space-time coordination dynamics in basketball: Part 2. The interaction between the two teams. Journal of Sports Sciences, 28(3), 349-358. doi: $10.1080 / 02640410903503640$

5. Clemente, F. M., Couceiro, M. S., \& Martins, F. M. L. (2012). Towards A New Method to Analyze The Soccer Teams Tactical Behaviour : Measuring The Effective Area of Play. Indian Journal of Science and Technology, 12(5), 3792-3801..

6. Correia, V., Araújo, D., Davids, K., Fernandes, O., \& Fonseca, S. (2011). Territorial gain dynamics regulates success in attacking subphases of team sports. Psychology of Sport and Exercise, 12(6), 662-669. doi:10.1016/j.psychsport.2011.06.001

7. Davids, K., \& Araújo, D. (2010). The concept of "Organismic Asymmetry" in sport science. Journal of science and medicine in sport / Sports Medicine Australia, 13(6), 633-40. doi:10.1016/j.jsams.2010.05.002

8. Folgado, H., Lemmink, K. a. P. M., Frencken, W., \& Sampaio, J. (2012). Length, width and centroid distance as measures of teams tactical performance in youth football. European Journal of Sport Science, 14:sup1, 487-492, doi: 10.1080/17461391.2012.730060

9. Fonseca, S., Milho, J., Travassos, B., \& Araújo, D. (2012). Spatial dynamics of team sports exposed by Voronoi diagrams. Human movement science, 31(6), 1652-9. doi:10.1016/j.humov.2012.04.006

10. Fonseca, S., Milho, J., Travassos, B., Araújo, D., \& Lopes, A. (2013). Measuring spatial interaction behavior in team sports using superimposed Voronoi diagrams. Journal of Performance Analysis in Sport, 13(1), 179-189.

11. Frencken, W., \& Lemmink, K. A. P. M. (2008). Team kinematics of small-sided soccer games. A systematic approach. In T. Reilly \& F. Korkusuz (Eds.), Science and football VI: Proceedings of the 6th World (pp. 161-166). New York, NY: Routledge.

12. Frencken, W., Lemmink, K., Delleman, N., \& Visscher, C. (2011). Oscillations of centroid position and surface area of soccer teams in small-sided games. European Journal of Sport Science, 11(4), 215-223. doi:10.1080/17461391.2010.499967

13. Fujimura, A., \& Sugihara, K. (2005). Geometric Analysis and Quantitative Evaluation of Sport Teamwork. Systems and Computers, 36(6), 49-58

14. Garganta, J. (2009). Trends of tactical performance analysis in team sports: bridging the gap between research, training and competition.. Revista Portuguesa de Ciências do Desporto, 9(1), 81-89.

15. Gazimba, V., Duarte, R., \& Araújo, D. (2013). A interacção espáciotemporal dos jogadores e das equipas de Futebol captada através dos diagramas de Voronoi. Gymnasium - Revista de Educação Física, Desporto e Saúde, 3(1), 118-138.

16. Glazier, P. (2010). Game, set and match? Substantive issues and future directions in performance analysis. Sports Medicine (Auckland, N.Z.), 40(8), 625-634. doi:10.2165/11534970-000000000-00000

17. Glazier, P., Davids, K., \& Bartlett, R. (2003). Dynamical systems theory: a relevant framework from performance-oriented sports biomechanics research. Sport Science, 7, 85-92.

18. Gréhaigne, J. F., Godbout, P., \& Bouthier, D. (1999). The foundations of tactics and strategy in team sports. Journal of Teaching in Physical Education, 18, 159-174.

19. Gréhaigne, J., \& Godbout, P. (2014). Dynamic Systems Theory and Team Sport Coaching. Quest (00336297), 66(1), 96-116.

20. Kim, S. (2004). Voronoi analysis of a soccer game. Nonlinear Analysis: Modelling and Control, 9, 233-240.

21. Law, J. (2005). Analysis of Multi-Robot Cooperation using Voronoi Diagrams. Pace Pacing And Clinical Electrophysiology.

22. Lebed, F. (2006). System approach to games and competitive playing. European Journal of Sport Science, 6(1), 33-42. doi:10.1080/17461390500422820

23. Leser, R., Schleindlhuber, A., Baca, A. \& Keith, L. (2014). Accuracy of an UWB-based position tracking system used for time-motion analyses in game sports. European Journal of Sport Science, Epub ahead of print.

24. Lopes, A., Fonseca, S., Leser, R., \& Baca, A. (2013). Part 7 - Systems - 36. Using spatial metrics to characterize behaviour in small sided games. In D. Peters \& P. O’Donoghue (Eds.), Performance analyis of sport IX. London: Routledge.

25. Martins, F. M. L., Clemente, F. M., \& Couceiro, M. S. (2013). Mathematical Methods in Engineering International Conference. In Mathematical Methods in Engineering International Conference (pp. 1-15). Porto.

26. McGarry, T. (2009). Applied and theoretical perspectives of performance analysis in sport: Scientific issues and challenges. International Journal of Performance Analysis in Sport, 9(1), 128-140.

27. McGarry, T., Anderson, D. I., Wallace, S., Hughes, M. D., \& Franks, I. M. (2002). Sport competition as a dynamical selforganizing system. Journal of sports sciences, 20(10), 771-81. doi:10.1080/026404102320675620

28. McGarry, T., \& Franks, I. M. (2007). System approach to games and competitive playing: Reply to Lebed (2006). European Journal of Sport Science, 7(1), 47-53. doi:10.1080/17461390701216831

29. Mitchell, S., Oslin, J., \& Griffin, L. (2006). Teaching sport concepts and skills: A tactical games approach. Champaign, IL: Human Kinetics Publishers.

30. Moura, F. A., Martins, L. E. B., Anido, R. O., Ruffino, P. R. C., Barros, R. M. L., \& Cunha, S. A. (2013). A spectral analysis of team dynamics and tactics in Brazilian football. Journal of Sports Sciences, 31(14), 1568-77. doi:10.1080/02640414.2013.789920

31. Okihara, K., Kan, A., Shiokawa, M., Choi, C. S., Deguchi, T., Matsumoto, M., \& Higashikawa, Y. (2004). Compactness as a strategy in a football match in relation to a change in offense and defence. Journal of Sports Sciences, 22(6), 5.

32. Oliveira, J., \& Graça, A. (1998). O Ensino do Basquetebol In: A. Graça, J. Oliveira (eds.), O ensino dos Jogos Desportivos, pp. 61-94. Centro de Estudos dos Jogos Desportivos, Faculdade de Ciências do Desporto e de Educaçáo Física da Universidade do Porto, Porto.

33. Passos, P., Milho, J., Fonseca, S., Borges, J., Araújo, D., \& Davids, K. (2011). Interpersonal distance regulates functional grouping tendencies of agents in team sports. Journal of motor behavior, 43(2), 155-63. doi:10.1080/00222895.2011.552078

34. Reed, D., \& Hughes, M. (2006). An Exploration of Team Sport as a Dynamical System. David Reed and Mike Hughes. Centre for Performance Analysis, School of Sport, Physical Education and Recreation, University of Wales Institute Cardiff, Cyncoed Campus, CF23 6XD. International Journal of Performance Analysis in Sport, 6(2), 114-125.

35. Sampaio, J., \& Maçấs, V. (2012). Measuring Football Tactical Behaviour. Int J Sports Med, 33, 1-7. doi:http://dx.doi.org/ 10.1055/s-00311301320 
36. Taki, T., Hasegawa, J., \& Fukumura, T. (1996). Development of motion analysis system for quantitative evaluation of teamwork in soccer games. In IEEE International Conference on Image Processing, Proceedings (Vol. 3, pp. 815-8).

37. Travassos, B., Araújo, D., Correia, V., \& Esteves, P. (2010). Eco-Dy- namics Approach to the study of Team Sports Performance. The Open Sports Sciences Journal, 3, 56-57.

38. Voronoi, G. (1907). Nouvelles applications des paramètres continus à la théorie des formes quadratiques. Journal für die Reine und Angewandte Mathematik, 133, 97-178. 